\title{
Inhibitory Effect of Plant Extracts on Conidial Germination of the Phytopathogenic Fungus Fusarium oxysporum
}

\author{
Domenico Rongai $^{{ }^{*}}$, Filomena Milano ${ }^{1}$, Elisabetta Sciò $^{2}$ \\ ${ }^{1}$ Consiglio per la Ricerca e la Sperimentazione in Agricoltura, Centro di Ricerca per la Patologia Vegetale, Roma, Italy; ${ }^{2}$ Sapienza \\ University, Roma, Italy. \\ Email: *domenico.rongai@entecra.it
}

Received September $20^{\text {th }}, 2012$; revised October $24^{\text {th }}, 2012$; accepted November $15^{\text {th }}, 2012$

\begin{abstract}
In an attempt to reduce the use of synthetic fungicides, extensive investigations into the possible exploitation of plant compounds as natural commercial products were performed. The present paper describes the antifungal activity of botanic extracts on the development of Fusarium oxysporum, f.s.p. lycopersici. The tests in vitro were carried out in a multi-well plate assay. The tested plants were classified based on the optical density reached by germinating conidia 24 , 48 and 72 hours after inoculation. Among 500 plant species tested, about 84\% did not exert significant inhibition, 7.6\% showed low inhibition, $5.2 \%$ had an intermediate level of antifungal activity, and only $3 \%$ inhibited fungal germination completely. These findings suggest that some botanic extracts tested possess antifungal activities against Fusarium oxysporum and could be used as potential antifungal agents for the control of fungal plant diseases.
\end{abstract}

Keywords: Fusarium; Plant Extract; Antifungal Activity; Natural Fungicide

\section{Introduction}

In the past decades the use of fungicides to control crop disease has contributed to increased production of food worldwide. Nevertheless, the massive use of synthetic fungicides in crop defence had severe environmental impact. Synthetic fungicides also pose serious health risks within our food chain and have been linked to increased occurrence of several types of cancer. The increasing number of fungal population with enhanced resistance to common fungicides, on the other hand, urges the development for new formulations which are both effective and environmentally friendly. In this respect, plant extract may represent an ideal solution to the problem and can be easily tested in vitro, using a microtiter plate assay to rapidly evaluate plant extracts [1]. This study showed that, when tested against Botritys cinerea, high levels of antifungal activity were found in 13 of the 345 plant species, mainly among the families of Allium and Capsicum. Furthermore, [2] a strong antifungal activity detected in 22 different plant extracts against two soil pathogens, Fusarium solani and Rhizoctonia solani, and it hypothesised that their effect on the fungal mycelium comes both from the inhibition of enzymes withing the fungi and the a concomitant induction of en-

\footnotetext{
*Corresponding author.
}

dogenous plant proteins associated with defence against biotic stress. Aqueous extracts of 46 plants against Fusarium spp. [3] revealed that 12 plants have recorded significant antifungal activity and that these plants could be exploited for eco-friendly management. The results of a study on the inhibitory activity of extracts from Kenyan medicinal plants against three soil pathogens [4], showed that Warburia ugandensis, Azadirachta indica, Tagetes minuta and Urtica massaica were active against the fungus Fusarium oxysporum, Alternaria passiflorae and Aspergillus niger.

In recent years the Brassicacea family has drawn special interest due to its high levels of glucosinolates. The glycosidic compounds are have no biocidal activity in their native form but are converted via enzymatic hydrolysis to the active degradation products (mainly isothiocyanates), whose cytotoxic activity has been extensively documented. Many authors [5-9] have studied in vivo activity of seed flour of Brassicaceae species against soil which had been inoculated with fungal spores, however its use in biofumigation to control soil fungi has generated mixed results. For example, plant residues of Brassicaceae in the soil can enhance the growth of the fungus Pythium spp. [10]. Glucosinolates from seed meal of Brassica napus [11], strongly alter the soil microbiome (both pdathogenic and useful microor- 
ganisms). A comprehensive study carried out by [12] showed that the use of plant residues of Brassica spp. to control the soil fungui Pythium and Fusarium brought no substantial benefit in controlling the disease in melon crops. Two years of experiments showed that soil treated with B. napus and Brassica juncea suffered from increased infestation by Fusarium oxysporium and Pythium spp when compared to untreated soil.

In this study, we have developed an in vitro multiwall assay to determine the biocidal activity of botanic extracts against the phytopathogenic fungus $F$. oxysporum and applied the method on a wide panel of plant extracts and powders.

This work allowed us to select the best candidate extracts for future field trials, with the ultimate aim of developing a green alternative to synthetic fungicides.

\section{Materials and Methods}

\subsection{Plants, Extraction Method and Fungus Used}

All plant material was kindly provided by the botanical garden at "La Sapienza University", Rome. Fresh plant material of 500 different species was collected and stored in a freezer at $-20^{\circ} \mathrm{C}$. The plastic bag is crushed with a pestle and the fluid collected in a test tube. The extract was centrifuged and the supernatant filtered through a $0.22 \mu \mathrm{m}$ membrane filter. Plant extracts were tested on a suspension of 7 day old conidia $\left(1 \times 10^{5}\right.$ conidia per ml) of Fusarium oxysporum f.s.p. lycopersici (strain CRAPAV collection n. ER1372) using a hemocytometer.

\subsection{Operations Reading of Multiwell Plates and Evaluation of the Conidia Germination}

Two hundred $\mu 1$ of a mixture containing: $80 \mu 1$ of conidial suspension, $100 \mu \mathrm{l}$ of Czapek Dox Broth and $20 \mu \mathrm{l}$ of plant extract, were pipetted into each well of the microtitration plate. One plate row was filled with untreated spore suspension in Czapek Dox Broth as a negative control. Changes in optical density following conidial germination were measured 24, 48 and $72 \mathrm{~h}$ after inoculum using a microplate reader (Multiscan-Plus MK II, Labsystems OY, Helsinki, Finland) at a wavelength of 405 $\mathrm{nm}$. This setup allowed the analysis of 23 different samples in four replicates. Optical densities were recorded 24, 48 and 72 hours after inoculation and then averaged. Conidial germination 24 hours after inoculation was assessed by mounting $10 \mu \mathrm{l}$ samples on a glass slide and counting the number of germinated spores at $160 \times$ magnification. The percentage germination recorded for the four wells was averaged.

The plant extracts were clustered into four classes based on the sum of difference of absorbance (DA) at 24, 48 and 72 hours and of the fungal growth in the wells of the microtiter plates. The four classes were: 1) DA be- tween 0 to 0.14 and no F. oxysporum conidia germination observed after 24 hours; 2) DA between 0.15 to 0.8 and $<40 \%$ conidia germinated; 3) DA between 0.81 to 1.40 and about $40 \%-80 \%$ conidia germinated; 4) DA > 1.41 and $>80 \%$ conidia germinated observed after 24 hours.

\subsection{Statistical Analysis}

Statistical analysis ANOVA was carried out and mean values were compared by Fisher's protected LSD test at $P \leq 0.05$. SigmaPlot version SPW 10 and Sigma Stat version 3.5 were used to create graphics.

\section{Results}

Among 500 plant extracts tested, 420 (more than 84\%) did not reduce the conidial germination and, in some instances, enhanced it. Thirty-eight plant species (7.6\%) displayed low fungal inhibition, while 26 of them (about $5.2 \%$ ) had an intermediate level of antifungal activity, and only 15 extracts (corresponding to the $3 \%$ ) completely inhibited fungal germination (Figure 1).

Analysis of optical density and fungal growth in the wells shows a high correlation $\left(\mathrm{R}^{2}=0.96\right)$ between the sum of DA at 24, 48 and $72 \mathrm{~h}$ and the percentage of conidia germination observed after $24 \mathrm{~h}$ (Figure 2). It is interesting to notice that plant extracts with the sum of DA under 0.2 completely inhibited conidial germination after $24 \mathrm{~h}$. Most of extracts with high antifungal activity, in fact, showed even negative values after $24 \mathrm{~h}$ due, probably, to decantation of compounds present in the extract. In addition, in this group, very low values of DA were registered also after 72 hours (Table 1).

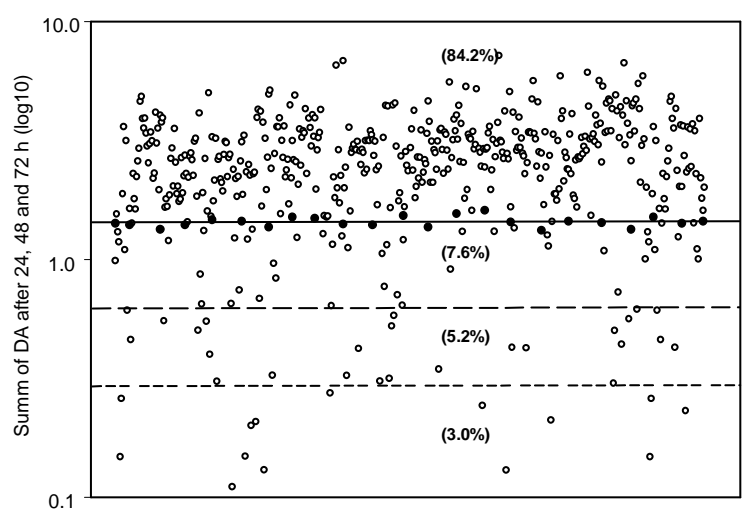

Figure 1. The totality of plant extracts tested for antifungal activity. Each circle represents one plant extract. The black circles symbolize the control and the solid line its average. Above this line, the extracts induce an increase of conidial germination, while below it are plant species able to reduce conidial germination. Of all plants, $7.6 \%$ has got a low level of antifungal activity, $5.2 \%$ an intermediate level and only the $3 \%$ of the extracts show a high level of antifungal activity. 


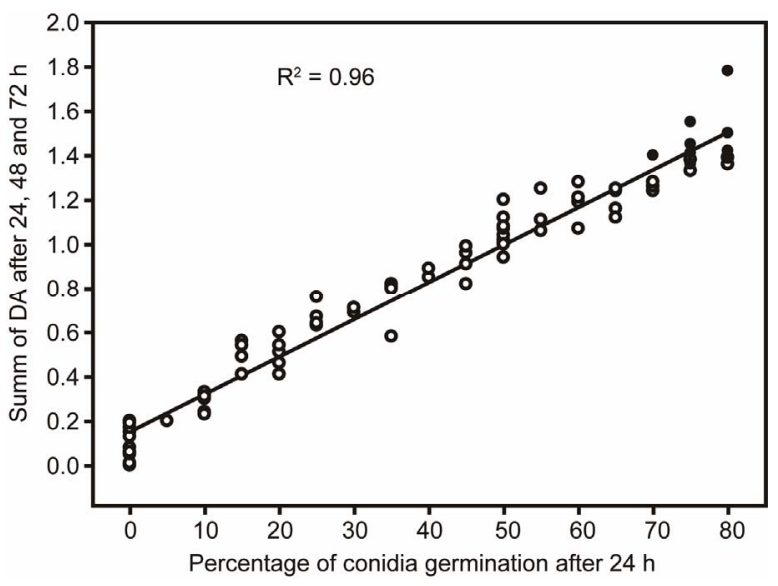

Figure 2. Linear regression between the values of difference of absorbance and the percentage of conidia germination of plant species with different grades of antifungal activity. Each circle represents a plant extract. The black circles symbolize the control.

Plant with intermediate antifungal activity were characterised also by low values of DA after $24 \mathrm{~h}$, in some cases they were registered negative values (Table 2). After $72 \mathrm{~h}$, however, the medium value of DA was 0.30 , while the average of conidia germination registered in this group was above $20 \%$.

Plant extracts characterized by a low antifungal activity showed the high values at 24,48 and $72 \mathrm{~h}$, in some cases reaching the values registered for the control (Table 3). After $72 \mathrm{~h}$ the medium values of DA was 0.59 and in most extracts the value was not significantly different from the control value. In this group the average of conidial germination was more than $60 \%$.

At last, the most extracts showed no antifungal activity. This group of plants, also after only $24 \mathrm{~h}$, has registered a very high level of the DA much superior than control (see Figure 1, circles symbolized above solid line). For those extracts the valuation of conidia germination was carried out random. In all examined extracts conidial germination $(>80 \%)$ was higher than in the negative control.

\section{Discussion}

According to some authors, the use of plant molecules for the control of phytopathogens exceed $4 \%$ of the pesticide market within a few years. The substitution of synthetic fungicides with ecofriendly products is holds great potential because the use of pesticides will be increasingly restricted by European regulation for their undesired side effects such as recalcitrance to degradation, accumulation in the food chain and interference with soil microbiology. Finally, there is the economic aspect, the possibility of using plant molecules in crop protection, in fact, even as carriers or dispersants used as such or for the production of co-formulants, requires large quantities with positive effects on agricultural income.

In our research, we have used the soil pathogen $F$. oxysporum, causal agent of a disease known as "wilts".

Table 1. Plant extracts with the highest antifungal activity. Values with different letters are statistically different (LSD test, $P \leq$ 0.05).

\begin{tabular}{|c|c|c|c|c|c|c|}
\hline \multirow[t]{2}{*}{ Genus } & \multirow[t]{2}{*}{ Species } & \multirow[t]{2}{*}{ Common name } & \multirow[t]{2}{*}{ Family } & \multicolumn{3}{|c|}{$\begin{array}{c}\text { Difference of assorbance } \\
\text { after inoculation }\end{array}$} \\
\hline & & & & $24 \mathrm{~h}$ & $48 \mathrm{~h}$ & $72 \mathrm{~h}$ \\
\hline Control & & & & $0.21 \mathrm{a}$ & $0.41 \mathrm{a}$ & $0.79 \mathrm{a}$ \\
\hline Allium & sativum & Garlic & Alliaceae & $0.01 \mathrm{c}$ & $0.00 \mathrm{~d}$ & $0.00 \mathrm{~d}$ \\
\hline Allium & triquetrum & Angled onion & Alliaceae & $0.05 \mathrm{c}$ & $0.04 d$ & $0.1 \mathrm{c}$ \\
\hline Arctium & lappa & Greater burdock & Asteraceae & $-0.04 \mathrm{~d}$ & $0.03 \mathrm{~d}$ & $0.1 \mathrm{c}$ \\
\hline Brassica & carinata & & Brassicaceae & $0.02 \mathrm{c}$ & $0.01 \mathrm{~d}$ & $0.00 \mathrm{~d}$ \\
\hline Brunfelsia & calycina & Yesterday-today-tomorrow & Solanaceae & $-0.04 d$ & $0.01 \mathrm{~d}$ & $0.0 \mathrm{~d}$ \\
\hline Celtis & glabrata & Hackberry & Cannabaceae & $-0.25 \mathrm{~d}$ & $-0.25 \mathrm{~d}$ & $-0.3 \mathrm{~d}$ \\
\hline Citrus & limon & Limon & Rutaceae & $-0.25 \mathrm{~d}$ & $-0.1 \mathrm{~d}$ & $0.14 \mathrm{bc}$ \\
\hline Coffea & arabica & Coffea arabica & Rubiaceae & $0.0 \mathrm{~d}$ & $0.04 d$ & $0.01 \mathrm{~d}$ \\
\hline Cycas & revoluta (fruit) & Sago cycad & Cycadaceae & $-0.01 d$ & $0.02 \mathrm{~d}$ & $0.06 \mathrm{c}$ \\
\hline Lactuca & virosa & Wild lettuce & Asteraceae & $-0.07 \mathrm{~d}$ & $0.04 \mathrm{~d}$ & $0.09 \mathrm{c}$ \\
\hline Petrea & volubilis & & Verbenaceae & $-0.26 \mathrm{~d}$ & $-0.29 \mathrm{~d}$ & $0.13 \mathrm{bc}$ \\
\hline Punica & granatum (peel) & Pomegranate & Lythraceae & $0.13 b$ & $0.03 \mathrm{~d}$ & $0.08 \mathrm{c}$ \\
\hline Rivina & humilis & Pigeonberry & Phytolaccaceae & $-0.12 \mathrm{~d}$ & $-0.08 \mathrm{~d}$ & $0.06 \mathrm{c}$ \\
\hline Salvia & guaranitica & & Lamiaceae & $0.00 \mathrm{~d}$ & $0.04 \mathrm{c}$ & $0.09 \mathrm{c}$ \\
\hline Teucrium & scorodonia & Woodland germander & Lamiaceae & $-0.08 \mathrm{~d}$ & $-0.03 \mathrm{~d}$ & $0.2 b$ \\
\hline
\end{tabular}


Table 2. Plant extracts with intermediate antifungal activity. Values with different letters are statistically different. (LSD test, $P$ $\leq \mathbf{0 . 0 5})$.

\begin{tabular}{|c|c|c|c|c|c|c|}
\hline \multirow{2}{*}{ Genus } & \multirow{2}{*}{ Species } & \multirow{2}{*}{ Common name } & \multirow{2}{*}{ Family } & \multicolumn{3}{|c|}{ Difference of assorbance after inoculation } \\
\hline & & & & $24 \mathrm{~h}$ & $48 \mathrm{~h}$ & $72 \mathrm{~h}$ \\
\hline Control & & & & $0.21 \mathrm{a}$ & $0.41 \mathrm{a}$ & $0.79 \mathrm{a}$ \\
\hline Agave & underwoodii & & Agavaceae & $-0.08 \mathrm{~d}$ & $0.09 \mathrm{c}$ & $0.22 b$ \\
\hline Akebia & quinata & Chocolate Vine & Lardizabalaceae & $-0.04 d$ & $0.01 \mathrm{~d}$ & $0.19 \mathrm{c}$ \\
\hline Ballota & nigra & Black horehound & Lamiaceae & $0.04 \mathrm{c}$ & $0.09 \mathrm{c}$ & $0.2 \mathrm{cb}$ \\
\hline Borago & officinalis & Starflower & Boraginaceae & $0.04 \mathrm{c}$ & $0.13 \mathrm{c}$ & $0.32 \mathrm{bc}$ \\
\hline Cestrum & parquii & & Solanaceae & $0.17 \mathrm{a}$ & $0.18 \mathrm{c}$ & $0.32 \mathrm{bc}$ \\
\hline Chrysanthemum & ornatum & Mums & Asteraceae & $0.02 \mathrm{c}$ & $0.22 b c$ & $0.32 b$ \\
\hline Citrus & sinensis & Orange & Rutaceae & $0.08 b$ & $0.19 \mathrm{cb}$ & $0.31 \mathrm{ba}$ \\
\hline Dasylirion & acrotrichum & Great Desert Spoon & Ruscaceae & $-015 d$ & $0.14 \mathrm{c}$ & $0.4 \mathrm{ba}$ \\
\hline Helleborus & niger & Christmas rose & Ranunculaceae & $-0.01 \mathrm{~d}$ & $0.14 \mathrm{c}$ & $0.16 \mathrm{c}$ \\
\hline Iberis & sempervirens & Iberis & Brassicaceae & $0.06 \mathrm{c}$ & $0.23 b c$ & $0.34 \mathrm{~b}$ \\
\hline Kerria & japonica & Kerria & $\underline{\text { Rosaceae }}$ & $-0.02 \mathrm{~d}$ & $0.22 b c$ & $0.54 \mathrm{~b}$ \\
\hline Leonurus & cardiaca & Motherwort & Lamiaceae & $0.08 b$ & $0.27 \mathrm{~b}$ & $0.16 \mathrm{c}$ \\
\hline Ligustrum & lucidum & Glossy Privet & Oleaceae & $0.04 \mathrm{c}$ & $0.09 \mathrm{c}$ & $0.07 \mathrm{c}$ \\
\hline Lonicera & fragrantissima & Honeysuckle & Caprifoliaceae & $0.07 \mathrm{c}$ & $0.11 \mathrm{c}$ & $0.12 \mathrm{c}$ \\
\hline Magnolia & grandiflora & Bull bay & Magnoliaceae & $0.06 \mathrm{c}$ & $0.11 \mathrm{c}$ & $0.29 b$ \\
\hline Melissa & officinalis & Lemon balm & Lamiaceae & $0.07 \mathrm{c}$ & $0.16 \mathrm{c}$ & $0.09 \mathrm{c}$ \\
\hline Nerium & oleander & Oleander & Apocynaceae & $0.05 \mathrm{c}$ & $0.17 \mathrm{c}$ & $0.11 \mathrm{c}$ \\
\hline Pennisetum & villosum & Feathertop grass & Poaceae & $-0.09 \mathrm{~d}$ & $0.11 \mathrm{c}$ & $0.49 b$ \\
\hline Phytolacca & dioica & Pokeweeds & Phytolaccaceae & $0.13 b$ & $0.14 \mathrm{c}$ & $0.27 \mathrm{c}$ \\
\hline Rhamnus & alaternus & Alaterno & Rhamnaceae & $0.08 b c$ & $0.21 \mathrm{cb}$ & $0.35 b$ \\
\hline Rhaphiolepis & indica & India Hawthorn & Rosaceae & $0.11 b$ & $0.24 b c$ & $0.29 \mathrm{bc}$ \\
\hline Rosa & banksiae & Lady Banks' Rose & Rosaceae & $0.09 \mathrm{~b}$ & $0.15 \mathrm{c}$ & $0.07 \mathrm{~d}$ \\
\hline Rubia & tinctorum & Common madder & Rubiaceae & $0.15 b$ & $0.23 b c$ & $0.38 b$ \\
\hline Santolina & chamaecyparissus & Cotton lavender & Asteraceae & $-0.09 \mathrm{~d}$ & $0.05 \mathrm{~d}$ & $0.36 \mathrm{~b}$ \\
\hline Tanacetum & cinerariifolium & Dalmatian chrysanthemum & Asteraceae & $0.08 \mathrm{bc}$ & $0.28 b$ & $0.33 b$ \\
\hline Vinca & minor & Lesser periwinkle & Apocynaceae & $0.03 \mathrm{c}$ & $0.00 \mathrm{~d}$ & $0.2 \mathrm{cb}$ \\
\hline
\end{tabular}

This disease occurs in many plant species, including grasses, legumes and horticultural crops. It is very difficult the crop protection against those soil pathogens, especially now that is no more admitted the use of Methyl bromide as a fumigant.

Italy, being a country with an intensive agricultural, the control of the soil borne infections has always represented a serious problem. The genus Fusarium is one of the major fungal genera responsible for diseases on several crops. There are many alternative strategies to reduce the use of fungicides, including the use of resistant plant varieties, health certificated seed, phytosanitary measures, good cultural practices, water management, biofumigations, soil solarisation, biological control, the use of natural fungicides obtained from plants etc. This last aspect would seem the most effective to reduce the use of synthetic fungicides $[3,13]$.

The aim of this research was to identify the best plant or group of plants with a high level of antifungal activity against Fusarium spp. The plants with high or intermediate fungal activity have been 42 on the 500 plant extracts tested. They belong to different families, mainly Alliaceae (Allium sativum and A. triquetrum); Apocynaceae (Vinca minor and Nerium oleander); Asteraceae (Arctium lappa, Lactuca virosa, Chrysanthemum ornatum, Santolina chamaecyparissus and Tanacetum cinerariifolium); Brassicaceae (Brassica carinata and Iberis sempervirens); Cannabaceae (Celtis glabrata); Lamiaceae (Salvia guaranitica, Teucrinium scorodonia, Melissa officinalis); Lythraceae (Punica granatum); Phytolaccaceae (Rivina humulis, Phytolacca dioica); Rutaceae (Citrus limon, C. sinensis); Solanaceae (Brunfelsia caly- 
Table 3. Plant extracts with the low antifungal activity. Values with different letters are statistically different (LSD test, $P \leq$ 0.05).

\begin{tabular}{|c|c|c|c|c|c|c|}
\hline \multirow{2}{*}{ Genus } & \multirow{2}{*}{ Species } & \multirow{2}{*}{ Common name } & \multirow{2}{*}{ Family } & \multicolumn{3}{|c|}{ Difference of assorbance after inoculation } \\
\hline & & & & $24 \mathrm{~h}$ & $48 \mathrm{~h}$ & $72 \mathrm{~h}$ \\
\hline Control & & & & $0.21 \mathrm{a}$ & $0.41 \mathrm{a}$ & $0.79 \mathrm{a}$ \\
\hline Agapanthus & africanus & African lily & Lyliaceae & $0.21 \mathrm{a}$ & $0.2 \mathrm{bc}$ & $0.41 b$ \\
\hline Agathis & robusta & Queensland Kauri & Araucariaceae & $0.2 \mathrm{a}$ & $0.2 b$ & $0.62 \mathrm{a}$ \\
\hline Agrimonia & eupatoria & Sticklewort & Rosaceae & $0.22 \mathrm{a}$ & $0.40 \mathrm{a}$ & $0.62 \mathrm{a}$ \\
\hline Asparagus & officinalis & & Asparagaceae & $0.21 \mathrm{a}$ & $0.29 \mathrm{~b}$ & $0.46 b$ \\
\hline Atropa & belladonna & Belladonna & Solanaceae & $0.21 \mathrm{a}$ & $0.42 \mathrm{a}$ & $0.53 \mathrm{ba}$ \\
\hline Boehmeria & nivea & Ramie & Urticaceae & $0.19 \mathrm{a}$ & $0.39 \mathrm{a}$ & $0.43 b$ \\
\hline Butia & capitata (fruit) & Pindo Palm & Arecaceae & $0.14 b$ & $0.14 \mathrm{c}$ & $0.78 \mathrm{a}$ \\
\hline Choisya & ternata & Mexican orange blossom & Rutaceae & $0.15 b$ & $0.39 \mathrm{a}$ & $0.58 \mathrm{ab}$ \\
\hline Cistus & monspeliensis & Montpelier cistus & Cistaceae & $0.23 \mathrm{a}$ & $0.3 b$ & $0.54 \mathrm{~b}$ \\
\hline Cleistocactus & smaragdiflorus & & Cactaceae & $0.19 \mathrm{a}$ & $0.41 \mathrm{a}$ & $0.76 \mathrm{a}$ \\
\hline Convolvulus & arvensis & Bindweed & Convolvulaceae & $0.19 \mathrm{a}$ & $0.35 \mathrm{a}$ & $0.37 b$ \\
\hline Crinodendron & patagua & Lily of the valley tree & Elaeocarpaceae & $0.2 \mathrm{a}$ & $0.28 \mathrm{~b}$ & $0.76 \mathrm{a}$ \\
\hline Cycas & revoluta & Sago cycad & Cycadaceae & $0.21 \mathrm{a}$ & $0.42 \mathrm{a}$ & $0.48 b$ \\
\hline Dracaena & fragrans & Cornstalk Dracaena & Asparagaceae & $0.21 \mathrm{a}$ & $0.4 \mathrm{a}$ & $0.77 \mathrm{a}$ \\
\hline Duranta & plumieri & Duranta & Verbenaceae & $0.19 \mathrm{a}$ & $0.41 \mathrm{a}$ & $0.66 \mathrm{a}$ \\
\hline Echium & candicans & Pride of Madeira & Boraginaceae & $0.22 \mathrm{a}$ & $0.38 \mathrm{a}$ & $0.44 b$ \\
\hline Ferula & communis & & Apiaceae & $0.04 \mathrm{c}$ & $0.28 \mathrm{~b}$ & $0.53 \mathrm{ba}$ \\
\hline Glaucium & flavum & Yellow hornpoppy & Papaveraceae & $0.21 \mathrm{a}$ & $0.33 \mathrm{ab}$ & $0.65 \mathrm{a}$ \\
\hline Haworthia & cymbiformis & & Asphodelaceae & $0.18 \mathrm{a}$ & $0.37 \mathrm{a}$ & $0.78 \mathrm{a}$ \\
\hline Hydrangea & macrophylla & Bigleaf Hydrangea & Hydrangeaceae & $0.17 \mathrm{a}$ & $0.39 \mathrm{a}$ & $0.72 \mathrm{a}$ \\
\hline Koelreuteria & bipinnata & Chinese flame tree & Sapindaceae & $0.22 \mathrm{a}$ & $0.42 \mathrm{a}$ & $0.64 \mathrm{a}$ \\
\hline Lavandula & multifida & Fernleaf lavender & Lamiaceae & $0.19 \mathrm{a}$ & $0.41 \mathrm{a}$ & $0.79 \mathrm{a}$ \\
\hline Lobularia & maritima & Sweet alyssum & Brassicaceae & $0.09 \mathrm{bc}$ & $0.34 \mathrm{ab}$ & $0.64 \mathrm{ab}$ \\
\hline Mentha & suaveolens & Apple mint & Lamiaceae & $0.22 \mathrm{a}$ & $0.41 \mathrm{a}$ & $0.36 \mathrm{~b}$ \\
\hline Osmanthus & fragrans & Sweet osmanthus & Oleaceae & $0.21 \mathrm{a}$ & $0.39 \mathrm{a}$ & $0.65 \mathrm{a}$ \\
\hline Oxalis & acetosella & Common wood-sorrel & Oxalidaceae & $0.06 \mathrm{cb}$ & $0.28 \mathrm{~b}$ & $0.48 b$ \\
\hline Pachypodium & lamerei & Palm of madagascar & Apocynaceae & $0.05 \mathrm{c}$ & $0.42 \mathrm{a}$ & $0.78 \mathrm{a}$ \\
\hline Parrotia & persica & Persian ironwood tree & Hamamelidaceae & $0.21 \mathrm{a}$ & $0.4 \mathrm{a}$ & $0.6 \mathrm{a}$ \\
\hline Pistacia & lentiscus & Lentisk & Anacardiaceae & $0.12 b$ & $0.16 \mathrm{c}$ & $0.43 b$ \\
\hline Primula & hortensis & Primula & Primulacee & $0.09 b$ & $0.33 b$ & $0.58 \mathrm{ab}$ \\
\hline Pterocarya & fraxinifolia & Caucasian wingnut & Juglandaceae & $0.16 \mathrm{ab}$ & $0.38 \mathrm{ab}$ & $0.58 \mathrm{ab}$ \\
\hline Rosa & foetida & Copper rose & Rosaceae & $0.22 \mathrm{a}$ & $0.41 \mathrm{a}$ & $0.62 \mathrm{a}$ \\
\hline Rosa & canina (fruit) & Dog rose & Rosaceae & $0.11 \mathrm{~b}$ & $0.18 \mathrm{c}$ & $0.6 \mathrm{a}$ \\
\hline Santolina & rosmarinifolia & & Asteraceae & $0.19 \mathrm{a}$ & $0.42 \mathrm{a}$ & $0.59 \mathrm{ba}$ \\
\hline Schinus & molle (fruit) & American pepper & Anacardiaceae & $0.21 \mathrm{a}$ & $0.2 \mathrm{bc}$ & $0.4 \mathrm{~b}$ \\
\hline Stranvaesia & nussia & & Rosaceae & $0.09 \mathrm{~b}$ & $0.29 \mathrm{~b}$ & $0.56 \mathrm{ba}$ \\
\hline Wollemia & nobilis & Wollemia & Araucariaceae & $0.13 b$ & $0.14 \mathrm{c}$ & $0.53 \mathrm{ba}$ \\
\hline Zamioculcas & zamiifolia & Zanzibar gem & Araceae & $0.18 \mathrm{a}$ & $0.4 \mathrm{a}$ & $0.5 \mathrm{ba}$ \\
\hline
\end{tabular}


cina); Verbenaceae (Petrea volubilis). Among those plants, this research has been able to detect 15 plant extracts capable to inhibit completely conidial germination of $F$. oxysporum. Some of those plants "Brassicaceae" have a high content of glucosinolates that, after enzymatic-catalysed hydrolysis, produce cytotoxic compounds with antifungal activity. The mechanisms of action are still not clear but, the S-containing compounds such as carbon disulfide, dimethyl disulfide, dimethyl sulfide and methanethiol produced during degradation of glucosinolates, could have an important role in suppression of fungi. Other plant extracts are rich of allicin, saponins, terpenes, phenolics and others. Antifungal activities of allicin (Alliaceae) could be attributed to its interaction with the thiol group of proteins and amino acids. Another antifungal mechanism could be the allicin-mediated lipoperoxide production in fungal plasma membrane with increased permeability. With regard to the saponins, their mechanism of antifungal action is not well understood but, it is thought that they complex with sterols in the cell membrane, leading to pore formation and consequent loss of membrane integrity. The antifungal efficacy of terpenes contained in Asteracea family, could be due at the structural modifications in mycelial fungi and alterations in hyphal morphology. In the Lythraceae family, moreover, some phenolics compounds like the punicalagin may be responsible in inhibiting of the fungal mycelial growth. To conclude, those plant species could be exploited further through the purification and characterization of their antifungal compounds. In addition, those bioactive products could be formulated and used in ecofriendly strategies for crop disease control.

\section{Acknowledgements}

This work was supported by the project "EXTRAVALORE-Valorizzazione dei sottoprodotti della filiera del biodiesel" financed by the Italian Ministry of agriculture, food and forestry.

\section{REFERENCES}

[1] C. L. Wilson, J. M. Solar, A. El Ghaouth and M. E. Wisniewski, "Rapid Evaluation of Plant Extracts and Essential Oils for Antifungal Activity Against Botrytis cinerea," Plant Disease, Vol. 81, No. 2, 1997, pp. 204210. doi:10.1094/PDIS.1997.81.2.204

[2] H. Abd El Khair and G. El Gamal Nadia, "Effects of Aqueous Extracts of Some Plant Species against Fusarium solani and Rhizoctonia solani in Phaseolus vulgaris Plants," Archives of Phytopathology and Plant Protection,
Vol. 44, No. 1, 2011, pp. 1-16. doi:10.1080/03235400802678436

[3] S. Satish, M. P. Raghavendra and K. A. Raveesha, "Antifungal Potentiality of Some Plant Extracts against Fusarium spp.," Archives of Phytopathology and Plant Protection, Vol. 42, No. 7, 2009, pp. 618-625. doi: $10.1080 / 03235400701287578$

[4] J. K. Rugutt, A. N. Ngigi, K. J. Rugutt and P. K. Ndalut, "Native Kenyan Plants as Possible Alternatives to Methyl Bromide in Soil Fumigation," Phytomedicine, Vol. 13, No. 8, 2006, pp. 576-583.

doi:10.1016/j.phymed.2003.08.005

[5] O. Daugovish, J. Downer, O. Becker, G. Browne and J. Dunniway, "Mustard-Derived Biofumigation for Vegetable Crops and Strawberries," Agroindustria, Vol. 3, No. 3, 2004, pp. 335-338.

[6] L. M. Manici, L. Lazzeri and S. Palmieri, "In Vitro Fungitoxic Activity of Some Glucosinolates and Their Enzyme-Derived Products toward Plant Pathogenic Fungi," Journal of Agricultural and Food Chemistry, Vol. 45, No. 7, 1997, pp. 2768-2773. doi:10.1021/jf9608635

[7] L. M. Manici, O. Leoni, L. Lazzeri, S. Galletti and S. Palmieri, "Fungitoxic Activity of Some Glucosinolate Enzyme Derived Products against the Main Soil-Borne Pathogens," Pesticide Science, Vol. 55, 1999, pp. 486488.

doi:10.1002/(SICI)1096-9063(199904)55:4<486::AID-PS 941>3.0.CO;2-1

[8] P. Marciano, M. Benetti, S. Odorizzi, L. Malaguti and L. Lazzeri, "In Vitro Effects of Glucosinolate Degradation Products on Sclerotinia spp. and Coniothyrium minitans," Agroindustria, Vol. 3, No. 3, 2004, pp. 371-374.

[9] F. Villeneuve, C. Raynal-Lacroix, C. Lempire and G. Maignien, "Possibility of Using Biofumigation in Vegetable Crops for Controlling Soilborne Pathogens," Agroindustria, Vol. 3, No. 3, 2004, pp. 395-398.

[10] G. E. Walker and B. G Morey, "Effect of Brassica and Weed Manures on Abundance of Tylenchulus semipenetrans and Fungi in Citrus Orchard Soil," Australian Journal of Experimental Agriculture, Vol. 39, No. 1, 1999, pp. 65-72. doi:10.1071/EA97116

[11] M.F. Cohen and M. Mazzola, "Effects of Brassica napus Seed Meal Amendment on Soil Populations of Resident Bacteria and Naegleria americana, and the Unsuitability of Arachidonic Acid as a Protozoanspecific Marker," Journal of Plankton Research, Vol. 16, No. 1-2, 2006, pp. 16-25.

[12] M. C. N. Samuel, M. B. Riley and A. P. Keinath, "Effect of Incorporation of Brassica spp. Residues on Population Densities of Soilborne Microorganisms and on Damping-off and Fusarium Wilt of Watermelon," Plant Disease, Vol. 92, No. 2, 2008, pp. 287-294. doi:10.1094/PDIS-92-2-0287

[13] J. Singh and G. Verma, "Overview, All Other about Pesticides,” Pesticide Information, Vol. 27, 2001, pp. 27-29. 